\section{Borodkina I., Borodkin H.}

\title{
DIGITAL COMPETENCIES ANALYSIS AS VECTOR OF HIGHER SCHOOL REFORMING
}

Об'єктом дослідження є цифрова грамотність. Існує багато методів оцінки рівня цифрової грамотності суспільства. Особлива увага приділяється конщептуальній моделі формування та оцінювання рівня цифрової грамотності, яка передбачає визначення всіх областей знань, вмінь та зв'язків, які слід розглянути для розвитку цифрової компетенцї.

Одним з найбільш проблемних місиь є те, що повномасштабна реалізація цифрових компетенцій, відповідно до кониептуальної моделі, в сучасному украйнському суспільстві суттєво ускладнена. Структура цифрових компетенцій для фахівиів різних галузей не гармонізована, вона не враховує особливих професійних потреб, на яких слід зосередити увагу при формуванні навчальних програм та навчальних матеріалів, призначених для формування відповідних иифрових навичок. Освітня реформа, яка зараз відбувається в Україні, принициово змінюе підходи, методи та технології навчання. При иьому вирішальні зміни в напрямку цифровізації освіти та надання різним групам населення навичок володіння відповідними иифровими компетенціями можуть бути досягнуті лише за умови державної підтримки освітніх реформ. Міжнародні стандарти вимірювання глобальної комп'ютерної грамотності в Україні тільки починають використовуватись, що не дозволяє громадянам Украйни повністю реалізовувати свій потенціал.

В ході дослідження була обгрунтована необхідність гармонійного впровадження цифрових технологій в навчальний процес університетів, визначено принципи розвитку України в цифровій спільноті та основи розвитку ї цифрової економіки. В роботі запропоновано авторську модель вимірювання цифрової компетенції студентів, яка є розвитком пірамідальної моделі иифрової грамотності. Ця модель зв'язує складові иифрової грамотності з процесами розвитку від загальних методів використання цифрових компетенцій до вдосконалення иифрових навичок, необхідних спеціалістам окремих галузей. Дуже важливо, що ия модель акцентує увагу на необхідності зміни цифрових компетенцій залежно від контексту професійної діяльності.

Ключові слова: цифрові компетенції, постіндустріальна освіта, інформаційне суспільство, иифрова грамотність, медіаграмотність, інформаиійна грамотність.

\section{Introduction}

Development of information technology, which has taken place over the past 50 years, has formed a fundamentally new world in which the use of external information resources is a natural consequence of globalization. First of all, this is manifested in the fact that devices connected to the Internet are used in all spheres of human life. Computers and the Internet penetrate all sectors of the economy. They create the preconditions for the formation and development of the digital economy. The introduction of digital technologies in various spheres of the economy significantly changed the style of our lives; working conditions and business.

All this means that mankind has reached a fundamentally new era of its existence - the era of post-industrial society, when the theoretical knowledge becomes decisive. This new era of human development is sometimes referred to as the «information society» or «society of knowledge» in view of the role of knowledge and information in the life of society. The main structure that produces and accumulates such knowledge is the university. The latter requires significant changes in the goals, content, forms, methods, tools and training organization as a whole.

The Europe 2020 strategy (EU agenda for growth and employment for the current decade) emphasizes smart, sustainable and inclusive growth as a way of overcoming the structural disadvantages of the European economy, increasing its competitiveness and productivity, and supporting a sustainable social market economy [1]. Thanks to the strategy of a single digital market, it is essential to open up digital opportunities for people and businesses and to strengthen Europe's position as a world leader in the digital economy [2].

The European Commission aims to create a comprehensive digital society that benefits from a single digital market. Creating smarter cities, improving access to e-governance, and providing e-health services will truly create a digital European society. All this becomes possible in the presence of a certain level of digital skills in all strata of society. The European Commission is developing a policy aimed at training European citizens in digital skills with initiatives such as the European Skills Program. These measures will help Europe's ever greater growth in digital society [3].

Therefore, it is very important to study the digital competences of Ukrainian society and suggest some ways to increase their level in line with the Europe 2020 strategy, especially in higher education.

\section{The object of research and its technological audit}

The object of research is digital literacy. There are many methods for assessing the level of digital literacy in society. 
Particular attention should be paid to the conceptual model of the formation and evaluation of the level of digital literacy.

The purpose of using this model is identification of all areas of knowledge, skills and connections that should be considered for the development of digital competence. The proposed structure is sufficiently flexible. It should be adapted to different target groups of students and digital users.

The main distinguishing features of this model are:

- The model is based on the structure of the European Qualifications Framework (EQF), taking into account the needs of knowledge, skills and approaches.

- The model provides a wide range of knowledge and skills that will fully teach people the digital competencies needed in the 21 st century.

- The model does not rely on special educational subjects. It can't be used directly in any curriculum. It should be considered as guidelines for more detailed development in the organization of a certain educational process.

- The model assumes the existence and expansion of interrelations and interdependencies between different thematic areas. This will allow to organize training in the most accessible form and taking into account the priority tasks. There are predefined requirements that establish the relationships between the skills and knowledge acquired. These requirements should be strictly observed.

- The model is structured in such a way that it can take into account the specific needs and levels of training of different target groups. It can be used to plan educational content (for example, which level of education should be provided by the government, employer or paid by student).

Full-scale implementation of digital competencies in all spheres of life of modern Ukrainian society, according to the model described above, has such disadvantages:

- The structure of digital competences for specialists from different fields is not harmonized, it does not take into account the special professional needs, which should focus on the formation of curricula and training materials designed to form the appropriate digital skills.

- Education of Ukraine is undergoing reform now: the approaches, methods and technologies of teaching are fundamentally changing. Significant changes in the digitization of education and the preparation of various groups of the population to the relevant digital competencies can only be achieved if the state supports the reforms aimed at digitizing Ukraine.

- The world-renowned digital certification system (ECDL certification) in Ukraine has not yet been widespread. This means that the standards of global computer literacy in Ukraine are not used, which does not allow Ukrainian citizens to fully realize their potential.

\section{The aim and objectives of research}

The aim of research is analysis of concepts such as «digital literacy», «digital competence» and «digital skills» as a way to overcome the structural disadvantages of Ukrainian education, increase its competitiveness and efficiency.
To achieve this aim, the following tasks need to be addressed:

1. To substantiate necessity of introduction of digital technologies in universities educational process.

2. To investigate ways and methods of digital technologies introduction into the system of Ukrainian education.

3. To identify the segments of the education system in which it is desirable to introduce digital technologies in the first place.

4. To substantiate the increase in the profitability of the education system through the introduction of digital technologies.

5. To develop the basic principles of the strategy of digital continuity in education.

\section{Research of existing solutions of the problem}

Digital technologies, services and systems today are extremely important for social development. They create new jobs and ensure the growth of all sectors of the economy, ranging from traditional enterprises to the most advanced high-tech enterprises. The data presented in [1,4] indicate that the digital economy today is an area with a hidden potential both in the European Union and in Ukraine. Therefore, according to [2, 3], one of Europe's top priorities is to create a single digital market over the next few years. According to calculations [1-3], the implementation of this initiative could lead to a significant improvement in the economic performance of the EU countries, amounting to 14 trillion EUR or 415 billion EUR per year, as well as help to create hundreds of thousands of new jobs [4].

More and more digital technologies are used in all branches of the economy. The study of these technologies should be included at universities educational process [5-7]. Issues related to the acquisition and use of digital skills in the professional activities of specialists of various directions are considered in works [8-10].

The authors of works [11, 12] comprehensively explore such concepts as «digital skills», «digital literacy», determine their interrelation with computer literacy. In [13] the place of computer, information and digital literacy in the system of post-industrial education is investigated.

The paper [14] substantiates that the development of a digital education strategy requires the development of the information and education space, the creation of an information and educational environment to support the continuous development of digital competence of teachers and students. The authors and portal developers [15] have made an attempt to demonstrate that the acquisition of digital competences is an ongoing, multilateral process that covers all aspects of the modern educational environment.

International studies [16] suggest that Ukraine is significantly behind the developed countries in matters of digitalization and informatization of society. Implementation of modern digital technologies takes place with considerable delay, there is no consolidated state strategy for the development of digital technologies in society. This slows the pace of creation and exchange of information, knowledge, experience and technology [17]. Digital education is one of the main factors of its reform, the main and priority task of the effective development of the information society in Ukraine [18]

The Incheon Declaration [19] was prepared and adopted by the World Education Forum, held in Incheon, the Korean 
Republic, in May 2015. This forum confirmed the need to direct the world community to a single updated digital agenda in education. This declaration reflects the general idea of how the world education should develop in the next 15 years. The «Education 2030» concept, proposed by the forum participants, proclaimed the need to «Ensure inclusive and fair education and create opportunities for lifelong learning for all» [19, 20].

Ukrainian Digital Strategy «Digital Program 2020» [18] involves the transformation of the Ukrainian economy from analog to digital. This is a continuation of initiatives of the Digital Agenda for Europe program in Ukraine.

In the works [21, 22], it is substantiated that the specialists of all sectors of the country's economy must have sufficient digital skills. However, this paper does not fully disclose the ways and methods that will allow digital competencies to be acquired in the relevant fields.

The analysis made allows to conclude that the single digital market is, first and foremost, the free movement of people, services and finance. Participants in this market should be able to carry out continuous economic activity subject to the highest level of protection of personal and consumer data. And this should not depend on citizenship, nationality or place of residence. At the same time, the single digital market requires the following conditions [23]:

- simplified access to services and goods for both individuals and entrepreneurs;

- the presence of specialists capable of working in a single digital market, a high level of digital skills; - uniform standards and rules for the provision of electronic and informational services;

- the only approaches to learning digital competence and the only techniques for measuring them.

\section{Methods of research}

In the study, the following scientific methods were used: - The method of analysis - used to divide the general concept of «digital competence» into constituent elements with the allocation of certain features inherent in certain sectors of the economy.

- The method of synthesis - used for combining dissected and investigated in the process of analysis of parts, establishing links between them and defined of «digital competencies» as a whole.

- The method of induction - used in a generalized consideration of digital technology and digital competencies in order to determine their common features. - The method of deduction - used when moving from the general perceptions of digital technology and digital competences to determining the properties and characteristics of individual competencies and skills.

- The method of abstraction - used in determining the features inherent in digital competences, and the essential links between them.

- The method of concretization - used in the study of specific features of individual digital competencies.

\section{Research results}

Dynamic changes in all spheres of the economy require Ukraine to use innovative strategies that will ensure the country's integration into the world economic space. In 2016, leading scientists in the field of information technology developed the «Digital Agenda of Ukraine 2020» [18]. The document defines the principles of Ukraine's development in the digital area and the basis for developing the digital economy. At this stage, it includes 10 areas: public safety, health protection, e-government, e-democracy, ecology, smart grids, electronic payments and payments, social sphere, electronic customs, electronic commerce.

Digital literacy is a broad and holistic concept that encompasses much more than the functional digital skills that students must use in a digital society. Despite the fact that many students are highly skilled in using modern digital technologies, they often do not possess all the digital competences they need for successful training and placement when entering a higher education institution. Declaration emphasizes the key role of universities in providing students with a variety of general and specialized skills in digital literacy. Studying at universities should develop digital literacy skills both in time and in aspects related to professional development and acquiring handson professional experience. The pyramidal model of digital literacy, proposed in [24], demonstrates how such development process enhances the digital literacy of students. This model links digital literacy with developmental processes from general concepts and methods of using digital rights (General entitlement) to specialist enhancements. The development comes from providing functional access («I have ...»), through the development of skills (Skills development, «I can ...») and the acquisition of practical experience (Situated practices, «I do ...») to higher-level capabilities, personality development (Identity development, «I am ...»). It is very important that this model emphasize the necessity of changing digital literacy depending on the context of professional activity. This means that throughout the life people can be motivated to acquire new digital skills and practices depending on different situations.

According to [25], competence is a dyadic combination of knowledge, skills and practical skills, ways of thinking, professional, ideological and civic qualities, moral and ethical values. It determines the person ability successfully carry out a professional and further educational activities. The competence is the result of learning at a certain level of education. Then digital competence is the ability of the user to confidently, effectively and safely choose and apply information and communication technologies in various spheres of life, based on the continuous mastery of knowledge, skills, motivation and responsibility.

Under digital consumption, the use of digital competent within certain life situations is understood, which results in the use (consumption) of various digital resources and Internet services for work and life.

Digital security is a combination of tools, security measures and skills that users need to ensure their safety in the digital world [26-28].

Digital literacy includes a number of skills and abilities. They are group into seven elements:

- media literacy - the ability to critically perceive and creatively re-think academic and professional communications in various media;

- information literacy - the ability to find, interpret, evaluate, manage and share information;

- ICT literacy - the ability to adopt, adapt and use cipher devices, applications and services;

- communication and collaboration - the ability to use digital networks for learning and research; 
- digital scholarships - participation in new academic, professional and research-based practices based on digital systems;

- learning skills - the ability to learn and effectively learn in formal and informal environments rich in technologies;

- career and management style - the ability to manage digital reputation and identity on the Internet.

The model of digital competence of students, developed as evolution of the pyramidal model and proposed by the authors, describes the components of the digital skills, which the modern student must possess. The model identifies five main areas of digital literacy that characterize different aspects of digital competence and can be measured by questionnaires and tests. Below is a description of this model in the form of a list of basic knowledge, skills and abilities. This model used by authors in assessing the level of digital competence of student.

1. Information management.

1.1. Search and view information - student determines the need for information and chooses methods for its search and viewing, uses alternative search techniques if necessary, justifies the advantage of the chosen method of information search, compares and creates effective methods of information seeking.

1.2. Assessment of information - student collects and processes digital information, allocates significant, critically analyzes and evaluates the adequacy, reliability and integrity of the information found, explains the general mechanisms of information processing.

1.3. Preservation and reproduction of information student stores information on digital media, organizes and processes collected information, correctly sends and reproduces digital materials, based on the generally accepted practice of intellectual property protection and licensing conditions established by the author.

2. Communication in digital environments.

2.1. Communication through digital means - using digital media and Internet applications, student communicates on social networks, participates in discussions on the Internet forum, uses mailing lists, observes the established rules, is able to choose the appropriate format, medium and method of communication.

2.2. Distribution of information and content - student shares the location and content of the information found, uses the Internet environment for the publication of digital materials, compares the advantages and disadvantages of distributing digital materials, which analyzes the value and adequacy of distributed information. Its actions are in accordance with the generally accepted practice of protecting intellectual property.

2.3. Civic activity on the Internet - student purposefully uses the university electronic educational environment, uses electronic services, offered by local self-government bodies and the state, purposefully uses the possibilities of a digital environment for participation in civil society.

2.4. Collaboration with the support of digital technology - student uses digital communication tools for remote and team work.

2.5. Network etiquette - in the practice of digital communication, student applies common standards of conduct, takes into account cultural characteristics and societhnic diversity.

2.6. Administration of digital identity - student forms, administers and protects his digital identity, tracks its digital «traces». Based on the context and purpose, student is able to express his identity and personality through digital means. 3. Content creativity.

3.1. Digital content creation - student independently creates, modifies and develops digital content in various formats, chooses appropriate software for collecting and processing data and presenting research results.

3.2. Creating new knowledge - in order to create new knowledge, student is able to modify and integrate existing digital materials, use a specific software solution.

3.3. Copyright and intellectual property protection - in the course of digital art and when using digital content created by others, student follows the license terms, copyright, and intellectual property rights protection.

3.4. Programming - student can apply programming languages and development environment to create programs of different levels of complexity.

4. Security.

4.1. Equipment protection - student consciously uses digital technology that allows you to take into account possible risks, takes the necessary security measures.

4.2. Protection of personal data - in its digital activity, student takes into account the right of people to the confidentiality of information, protects personal information from fraud and other dangers on the Internet.

4.3. Medical education - a student can assess the health risks associated with the use of digital media, knowingly avoiding the health risks caused by the use of digital technology and digital information.

4.4. Environmental protection - student is aware of the positive and negative aspects of using digital technologies, their environmental impact.

5. Solving problems.

5.1. Solutions to technical problems - student is able to identify technical problems and find possible solutions to eliminate them.

5.2. Finding the needs and finding ways to solve them student consciously chooses a digital solution, creatively and purposefully uses the possibilities of digital technology for solving life problems and improving the efficiency of own studies, evaluates technological capabilities and digital solutions that are combined with its needs.

5.3. Creative use of innovations and technologies - student purposefully uses digital means to present and solve problems, initiates cooperation for development of creative and innovative solutions, use digital means to solve the problems that arise in various spheres of everyday life.

5.4. Self-assessment of digital competence - student is able to assess the level of his/her own digital competence and opportunities for its development, is interested in new areas of digital technology development, systematically finds out and eliminates disadvantages in its digital competence, supports others in the development of digital competence.

\section{SWOT analysis of research results}

Strengths. The proposed principles of higher education reform will allow specialists to be trained in a post-industrial society. At the same time, the training of specialists will meet the requirements of the Europe 2020 strategy. The level of digital literacy of citizens will allow Ukraine to integrate with the European Union with minimal cost.

According to the Single Digital Market Strategy, the new principles of digital literacy open up digital opportunities 
for Ukrainian people and business, as a part and European one, as a world leader in the digital economy. This level will fully meet the requirements of the Single Digital Market too.

Weaknesses. Such approach will require radical changes in modern methods and means of teaching in higher education. It will be necessary to make large financial investments in the system of training people with higher education. This is a very challenging task in today's economic and political environment.

Opportunities. Future studies on digital education in Ukraine may relate to methods and approaches to study not only technical disciplines but also all the sciences that form the basis of higher education. These studies will be interesting (taking into account cultural characteristics) and for all Eastern Europe countries.

Threats. The main threat is the lack of modern teaching requirements in high school. In this case, the training level of people with higher education will not allow Ukraine, as part of the European community, to be at the level of modern requirements in the field of digital business.

\section{Conclusions}

1. The necessity of introducing digital technologies into the educational process of universities is grounded. The principles of Ukraine's development in the digital sphere and the basis for the development of its digital economy are determined. Universities should play a key role in providing students with a variety of general and specialized digital literacy skills.

2. The ways and methods of introduction of digital technologies into the system of Ukrainian education are investigated. It is determined that in Ukrainian universities it is advisable to use the pyramidal model of digital literacy proposed in [24]. This model combines the components of digital literacy with the development processes of the general methods of using digital competences to improve the digital skills required by specialists in individual industries. The development is due to the provision of functional access, through the development of skills and the acquisition of practical experience. It is very important that this model focuses on the need to change digital literacy depending on the context of professional activity.

3. The segments of the education system are identified, in which it is desirable to introduce digital technologies in the first place. In [18], 10 areas in which digitalization should be carried out in the first place are defined. These are public safety, health, e-governance, e-democracy, ecology, smart grids, electronic payments, social affairs, e-customs, e-commerce.

4. The increase in the profitability of the education system is justified, with the introduction of digital technologies. Investing in the digital skills of students and employees of educational, research and management organizations brings personal and organizational benefits, among which the first priority is the provision of quality education in a flexible and innovative way. This approach meets the expectations and needs of students, improves job opportunities, creates the potential for maximizing the return on investment in learning technology.

5. The basic principles of the strategy of digital continuity in education are developed. These principles are based on the need to send the Ukrainian community to a single digital education program, emphasizing the need for comprehensive and equitable education and the creation of opportunities for the education of all people throughout their lives. Implementation of these principles is possible subject to the following factors:

- conscious attitude of students towards learning;

- student activity;

- systematic and consistent, accessible learning process;

- unification of theory and practice;

- priorities of self-study;

- joint activities of students with classmates and teachers;

- use of existing experience and knowledge;

- correction of outdated personal experience;

- interference in the formation of new knowledge;

- individual approach to learning based on personal needs;

- rapid use of learning outcomes in practice.

\section{References}

1. Europe 2020 strategy // European Commission. URL: https:// ec.europa.eu/info/business-economy-euro/economic-and-fiscal-policy-coordination/eu-economic-governance-monitoring-preventioncorrection/european-semester/framework/europe-2020-strategy_en

2. Digital Single Market // European Commission. URL: https:// ec.europa.eu/digital-single-market/

3. Creating a digital society // European Commission. URL: https:// ec.europa.eu/digital-single-market/en/policies/creating-digitalsociety

4. Lindmark S. Web 2.0. Techno-economic analysis and assessment of EU position // Seville: European Commission - Joint Research Centre - Institute for Prospective Technological Studies, 2008. 57 p.

5. Livingstone S., Van Couvering E., Thumim N. Adult Media Literacy: a review of the research literature. Department of Media and Communications. London School of Economics and Political Science, 2005. 90 p. URL: https://core.ac.uk/download/ pdf/4155054.pdf

6. Martin A. Literacies for the Digital Age / ed. by Martin A., Madigan D. London: Facet, 2006. P. 3-25.

7. Martin A., Grudziecki J. DigEuLit: Concepts and Tools for Digital Literacy Development // Innovation in Teaching and Learning in Information and Computer Sciences. 2006. Vol. 5 , No. 4. P. 1-19. doi: http://doi.org/10.11120/ital.2006.05040249

8. Jenkins H. et al. Confronting the Challenges of Participatory Culture: Media Education for the 21st Century. MacArthur, 2006. 72 p.

9. Digital literacies: concepts, policies and practices / ed. by Lankshear C., Knobel M. New York: Peter Lang, 2008. 320 p.

10. Lenhart A., Fox S. A portrait of the internet's new storytellers. Washington, 2006. 33 p.

11. Ala-Mutka K. Mapping Digital Competence: Towards a Conceptual Understanding. Publications Office of the European Union, 2011. 62 p. URL: https://www.dctest.org/uploads/6/8/7/0/68701431/ jrc67075_tn.pdf

12. Horton F. W., Jr. Information literacy vs. computer literacy // Bulletin of the American Society for Information Science. 1983. Vol. 9, No. 4. P. 14-16.

13. Cole I. J., Kelsey A. Computer and information literacy in post-qualifying education // Nurse Education in Practice. 2004. Vol. 4, No. 3. P. 190-199. doi: http://doi.org/10.1016/ s1471-5953(03)00065-9

14. Ilomäki L., Kantosalo A., Lakkala M. What is digital competence? URL: http://linked-project.wikispaces.com/file/view/ Digital_competence_LONG+12.10.2010.docx

15. Martin A. Digital Literacy and the «Digital Society». New York: Peter Lang, 2008. P. 151-176.

16. Novikov A. M. Postindustrial education. Moscow: Egves, 2008. $136 \mathrm{p}$.

17. Hargittai E. Digital Na(t)ives? Variation in Internet Skills and Uses among Members of the «Net Generation»// Sociological Inquiry. 2010. Vol. 80, No. 1. P. 92-113. doi: http:// doi.org/10.1111/j.1475-682x.2009.00317.x

18. Digital Adzhda of Ukraine 2020. (Digital Agenda - 2020). Conceptual foundations. Priority areas, initiatives, projects of «digitalization» of Ukraine by 2020. 2016. URL: https:// ucci.org.ua/uploads/files/58e78ee3c3922.pdf 
19. Education-2030. Incheon Declaration. Ensuring universal inclusive and equitable quality education and lifelong learning for all. URL: http://unesdoc.unesco.org/images/0024/002456/245656R.pdf

20. Executive Summary: The Future of Jobs. 2016. URL: http://www3 weforum.org/docs/WEF FOJ Executive Summary Jobs.pdf

21. World Declaration on Higher Education for the Twenty-first Century: Approaches and Practical Measures // Herald of the highest school. 1999. No. 3. P. 29-35.

22. Information and communication technologies in education ed. by Dendev B. Moscow: UNESCO IITE, 2013. 320 p.

23. Groisman V. Digital Community: Ukraine and EU are preparing a joint project in the digital market // European truth. URL: http:// www.eurointegration.com.ua/rus/articles/2016/06/29/7051397

24. Quick guide - Developing students' digital literacy. URL: https://digitalcapability.jiscinvolve.org/wp/files/2014/09/JISC REPORT Digital Literacies 280714 PRINT.pdf

25. National Educational Glossary: Higher Education. Kyiv: Publishing House «Pleiades», 2014. 100 p.

26. Borodkina I. L., Borodkin G. O. Digital Literacy as a Factor in the Reform of Higher School // Young Scientist. 2017. No. 8. P. 395-399. URL: http://molodyvcheny.in.ua/files/journal $/ 2017 / 8 / 87 . p d f$
27. Borodkina I. L., Borodkin G. O. The quality of education and its assessment at a higher school in the context of the implementation of the principles of the Bologna Declaration // Empirical studies for reforming education in Ukraine. 2017. P. 200-202.

28. Borodkina I. L., Borodkin G. O. Statistical analysis of the results of testing in assessing the quality of education in higher education // Materials of the 1st International Scientific Conference «Ukraine-EU: Cross-cultural Comparisons in Educational Research». 2017. P. 17-22. URL: http://undip.org.ua/upload/ files/conference_proceedings_Kyiv_May\%2022-23.pdf

Borodkina Iryna, PhD, Associate Professor, Department of Computer Science, Kyiv National University of Culture and Arts, Ukraine, e-mail: borir@ukr.net, ORCID: https://orcid.org/0000-0003$3667-3728$

Borodkin Heorhii, Senior Lecturer, Department of Computer Science, National University of Life and Environmental Sciences of Ukraine, Kyiv, Ukraine, e-mail: george.borodkin@gmail.com, ORCID: https:// orcid.org/0000-0002-6488-6512

UDC 004.72:531.7.08

DOI: $10.15587 / 2312-8372.2018 .135486$

\section{Dudnik A. DEVELOPMENT OF METHOD OF INCREASING THE PERFORMANCE OF TOUCH NETWORKS OF MEASUREMENT OF DISTANCES}

Об'єктом дослідження є безпровідна сенсорна мережа протоколу ZigBeе, що в даному дослідженні пропонуються для виконання функиії вимірювання відстані між об'єктами. Основні сфери застосування - це охоронні об'єкти, такі як склади, магазини, виставки та експозиції, де важливо контролювати переміщення цінних речей на обмеженій території з великою концентрацією людей. Сенсори, що виконані на гнучкій основі, прикріплюються до цінних предметів та весь час передають між собою інформацію про відстань відносно один одного. Одним з найбільи проблемних місиь є обмежена пропускна спроможність каналів передачі даних. Також, для описаних вище приміщень характерні різного роду перешкоди, як механічні (стіни, перегородки, металеві полиці тощо), так і радіоперешкоди, наприклад, безпровідні мережеві інтерфейси телефонів покупців та інші.

В ході дослідження використовувався метод підвищення продуктивності безпровідних сенсорних мереж, що перебувають у складі комп'ютеризованих систем вимірювання відстані, побудованих на основі декомпозииіі нижніх рівнів еталонної моделі OSI.

Отримано ті ж самі показники пропускної спроможності, що й у аналогів, але навантаження, яке при ивому витримував мережевий вузол було у 2,5 рази більшим. Це пов'язано з тим, що запропонований метод підвищення продуктивності має ряд особливостей, які покращують характеристики продуктивності, зокрема в зонах невпевненого прийому майже в два рази.

Завдяки цьому забезпечується можливість роботи мережі з максимальною швидкістю 32,5 Мбіт/с. У порівнянні з аналогами, у яких максимальна швидкість становить 12,5 Мбіт/с, це забезпечує більш точні результати вимірювання відстані. Також, завдяки иьому запасу швидкості, забезпечується краща завадостійкість, а також можливість розташування мережевих вузлів на більших відстанях.

Ключові слова: сенсорна мережа, механічні величини, комп'ютеризована система вимірювання, інформащійно-вимірювальна система.

\section{Introduction}

The timely determination of the position of an object included in the wireless sensor networks results in the generation of false information in a computerized system for measuring the distance between objects. Such a disadvantage, in turn, can lead, for example, to untimely detection of theft of valuable things, a source of ignition, etc.
Particularly favorable environment, for this kind of negative effects is a clogged environment [1]. Among the various classes of computer information systems and networks, a special place is occupied by systems and networks whose transport service is based on the use of radio ester as a data transmission medium for computerized distance measuring systems (wireless sensor networks) [2]. Therefore, when creating the scientific basis for the construction of 